\title{
Spatial distribution of cancer stem cells in head and neck squamous cell carcinomas
}

\author{
Laura C. Hildebrand ${ }^{1}$, Ana L. Carvalho ${ }^{1}$, Isabel S. Lauxen ${ }^{1}$, Jacques E. Nör ${ }^{2}$, Carlos T. S. Cerski ${ }^{3}$, Manoel \\ Sant'Ana Filho ${ }^{1}$ \\ ${ }^{1}$ Oral Pathology, School of Dentistry, Universidade Federal do Rio Grande do Sul, Porto Alegre, Brazil; ${ }^{2}$ Angiogenesis Research \\ Laboratory, Department of Cariology, Restorative Sciences and Endodontics, School of Dentistry, University of Michigan, Ann Arbor, MI, \\ USA; ${ }^{3}$ Pathology Department, School of Medicine, Universidade Federal do Rio Grande do Sul, Hospital de Clínicas de Porto Alegre, \\ Porto Alegre, Brazil
}

BACKGROUND: CD44 and aldehyde dehydrogenase I (ALDHI) are considered putative markers of highly tumorigenic cells (i.e., cancer stem-like cells) in head and neck squamous cell carcinomas. This small subset of cells is believed to be the primary responsible for tumor initiation and progression. The objectives of this study were (i) to evaluate the patterns of CD44 and ALDHI expression in the tumor center and in the invasive front, as well as in adjacent non-tumor epithelium, and (ii) to correlate these findings with clinical parameters.

MATERIALS AND METHODS: The sample comprised 44 patients with primary head and neck squamous cell carcinomas. Hematoxylin and eosin (HE) staining was used for histopathological tumor grading and for morphological analysis of adjacent non-tumor epithelium. Semiquantitative analysis was performed in histological sections immunostained for CD44 and ALDHI.

RESULTS: ALDHI immunostaining in the invasive front showed positive association with tumor size, regional metastasis, tumor histopathological grading, and disease progression. Moreover, expression of this marker in both tumor invasive front and adjacent non-tumor epithelium was related with more aggressive tumors. CD44 immunostaining was heterogeneous in all areas evaluated and did not show association with clinical data.

CONCLUSION: Collectively, these data suggest that ALDHI immunostaining in the invasive front and in adjacent non-tumor epithelium may help identify tumors with a more aggressive behavior, potentially contributing to improving treatment customization and the monitoring of patients with head and neck cancer.

J Oral Pathol Med (2014) 43: 499-506

Correspondence: Manoel Sant'Ana Filho, PhD, Rua Ramiro Barcelos, 2492 Sala 503, Porto Alegre, RS, 90035-003, Brazil. Tel: +55 51 33085011, Fax: +55 51 33085010, E-mail: manoel@ufrgs.br

Accepted for publication January 6, 2014
Keywords: aldehyde dehydrogenase; CD44; head and neck squamous cell carcinomas; tumorigenesis; tumor-initiating cells

\section{Introduction}

Emerging evidence suggests that a small subset of cells in head and neck squamous cell carcinomas (HNSCCs) may be primarily responsible for tumor initiation and progression. This cell population has been shown to have an aggressive biological behavior, with the ability to self-renew and to generate heterogeneous lineages of cancer cells (1-15). These cells have characteristics that are similar to those of stem cells and have therefore been referred to as cancer stem-like cells (14-19).

The identification of highly tumorigenic cell populations could contribute to the development of novel therapeutic strategies and thus help mitigate the morbidity and mortality associated with cancer (3). The combination of markers that allow the identification of these cells is known to be tumor dependent. In HNSCCs, the markers most commonly used to identify highly tumorigenic cells are CD44 and aldehyde dehydrogenase 1 (ALDH1; 2, 8, 12, 14, 20, 21).

CD44 cells are a group of transmembrane glycoproteins that act on cell-cell and cell-matrix interactions (9, 22, 23), having hyaluronic acid (a widely abundant component of the extracellular matrix) as the main ligand (10, 23). The interaction between CD44 and hyaluronic acid activates essential characteristics of tumor progression, e.g., cell proliferation, survival, migration, and invasion (1, 10, 24-26). Some studies have reported a relationship between CD44 immunostaining results and tumor behavior $(9,11$, 24).

Aldehyde dehydrogenase 1 , in turn, is a cytosolic enzyme whose main function is to convert retinaldehyde into retinoic acid in retinol metabolism (27). The by-products of this metabolic process increase the self-renewal ability of mesenchymal stem cells $(27,28)$. ALDH1 activity is found in neoplastic cells, which show proliferative ability similar 
to that observed in stem cells and tumors with aggressive clinical behavior $(5,9,12,17,21,27-31)$.

While many studies have demonstrated that ALDH+ CD44+ cells are highly tumorigenic, it remains unknown whether the spatial distribution of these cells within human tumors can be correlated with clinical outcomes. This finding could be very useful in planning the postoperative clinical management of patients with HNSCC.

Therefore, the primary objective of this study was to assess the spatial distribution of CD44+ and ALDH1+ cells in two different areas of HNSCCs (tumor center and invasive front) and also in adjacent non-tumor epithelium in specimens obtained from surgically treated patients. Possible associations between immunostaining data and clinical parameters were also investigated.

\section{Materials and methods}

\section{Patients}

Our sample comprised 44 patients treated at the Head and Neck Surgery Outpatient Clinic of Hospital de Clínicas de Porto Alegre (HCPA). All patients presented with primary HNSCC and had not undergone chemotherapy or radiotherapy before surgery. Patient data, including gender, age, ethnic origin, and exposure to risk factors, were collected in an interview. Tumor location, size, regional and distant metastasis (pTNM; 32), treatment protocol, and 3-4-year follow-up data were also recorded. Outcome was classified as failure (local, regional, or distant metastasis and death due to tumor) and disease-specific survival. This study was approved by the Research Ethics Committee of the institution of origin (protocol no. 09-315).

\section{Immunohistochemistry}

Paraffin blocks containing tumor center, invasive front, and non-tumor epithelial specimens were selected for analysis. Three 3- $\mu$ m-thick sections were serially cut, of which two were used for CD44 and ALDH1 immunostaining and one for hematoxylin and eosin (HE) staining. Antigenic recovery was performed using Dako retrieval solution, citrate buffer pH 6.0 (Dako, Carpinteria, CA, USA), in water bath. Anti-CD44 antibody (clone EPR1013Y, rabbit, Abcam, Washington, DC, USA) was diluted at 1:100, and antiALDH1 antibody (clone 44, mouse, BD Transduction Laboratories, Franklin Lakes, NJ, USA) at 1:50. Nonspecific, isotype-matched $\mathrm{IgG}$ was used as a negative control.

\section{Histological analysis}

Hematoxylin and eosin-stained slides were graded according to the criteria set forth by Bryne et al. (33), into good, moderate, and poor prognosis. Non-tumor epithelial tissue located adjacent to HNSCC was classified according to morphological characteristics into unaltered tissue, epithelial hyperplasia, hyperkeratosis, acanthosis, and epithelial dysplasia. Epithelial dysplasia was defined as the presence of structural and cytological abnormalities confined to epithelial layers, without invasion of other tissues. CD44 and ALDH1 immunostaining was assessed in the entire area available, in both tumor and non-tumor epithelia. Cells presenting brown staining in the membrane and cytoplasm/ nucleus were considered positive for CD44 (Fig. 1) and ALDH1 (Fig. 2), respectively.

Immunohistochemical analysis was performed on both the invasive front and tumor center. The invasive front was defined as the deepest cancer cell islands (Figs $3 \mathrm{~d}$ and $\mathrm{m}$ ). Tumor center analysis focused on cancer cell islands located in the central region of the lesion, discarding areas of necrosis (Figs $3 \mathrm{~g}$ and $\mathrm{p}$ ). Adjacent non-tumor epithelium was considered normal when CD44 expression was observed in basal and parabasal layers, but not in superficial layers (Fig. 3L; 34).

Tumor markers CD44 and ALDH1 were semiquantitatively scored according to the proportion of cells stained in the whole sample as follows: 0 , negative; $1,<5 \%$ of positive cells; 2 , more than $5 \% ; 3,10-90 \%$; and 4 , more than $90 \%$ of positive cells (35). As the statistical analysis did not show differences in comparisons using four vs. two scores, CD44 and ALDH1 results were further classified into two groups, namely positive (more than 5\% of cells stained; Fig. 3B,C, $\mathrm{E}, \mathrm{F}, \mathrm{H}, \mathrm{I}$ ) and negative (less than $5 \%$ of cells stained; Fig. 3K,L,N,O,Q,R; 36).

\section{Data analysis}

All analyses were performed using the Statistical Package for the Social Sciences (SPSS), version 18. Results were tested for normality and revealed a normal distribution of data. Associations between CD44/ALDH1 staining results in the three regions assessed and clinical parameters were assessed using Pearson's chi-square test and Fisher's exact test (significance level set at $P<0.05$ ). Result reproducibility was confirmed over the study period by selecting one of every 20 slides (HE, CD44, and ALDH1) for reassessment after a 7-day interval $(\kappa>0.7)$. Examiners were blind to the site of origin of each specimen.

\section{Results}

Mean patient age was 58 years (range: $37-78$ years), and there was a male predominance of $86.4 \%$. Most patients were currently or formerly exposed to tobacco and alcohol. Detailed clinical data are summarized in Table 1. Of the 44

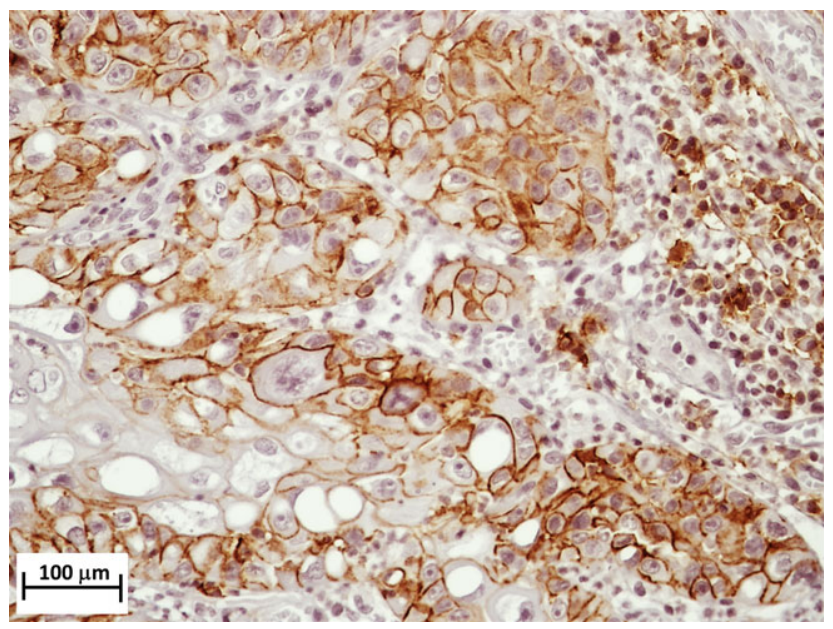

Figure 1 CD44-positive immunostaining in tumor cells. 400× magnification. 


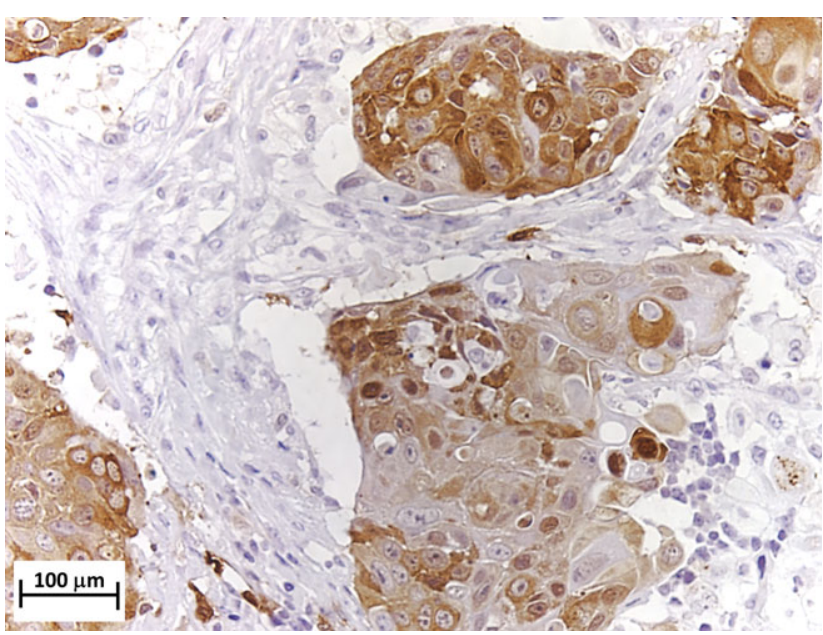

Figure 2 Aldehyde dehydrogenase 1-positive immunostaining in tumor cells. $400 \times$ magnification.

tumors assessed, $65.9 \%$ were $4 \mathrm{~cm}$ in diameter or smaller (T1 and T2), and $68.2 \%$ did not present regional metastases at the moment of assessment. None of the patients presented distant metastases. Most tumors were located in the oral cavity, most frequently affecting the tongue, lower lip, and floor of the mouth (Table 1).

Histopathological analysis revealed that $50 \%$ of the tumors were considered to be of good prognosis, $38.6 \%$ moderate, and $11.4 \%$ of poor prognosis. Most of the adjacent epithelium samples were classified as epithelial hyperplasia and hyperkeratosis (31.8\% each), followed by epithelial dysplasia (18.2\%). Normal epithelium was found in $13.6 \%$ of the samples (Table 1). Over the 3-4-year follow-up period, $68.2 \%$ of the patients were free from disease, whereas $25 \%$ showed disease recurrence/metastasis or died (Table 1).

An association was found between ALDH1 immunostaining results in tumor areas and in adjacent non-tumor epithelium, suggesting that ALDH1-positive tumors also tend to show ALDH1-positive non-tumor epithelium (Table 2). This association was not observed for CD44.

Table 3 shows CD44 and ALDH1 immunostaining results in tumor and non-tumor epithelium in association with clinical parameters and follow-up data. In the invasive front, associations were observed between ALDH1 immunostaining and tumor size (T3 and T4), presence of regional metastases (N1, N2, N3), and histopathological grading (good/moderate). Conversely, ALDH1 immunostaining in the tumor center did not show any association with the parameters assessed. In adjacent non-tumor epithelium areas, an association was observed between ALDH1 immunostaining and histopathological grading and followup data: $93.8 \%$ of the patients free from disease over the 34-year follow-up period showed ALDH1-negative cells in adjacent non-tumor epithelium $(P=0.019)$. These associations were not observed for CD44.

\section{Discussion}

Highly tumorigenic cancer stem-like cells present in HNSCC have been considered responsible for the aggressive
Highly tumorigenic cells in HNSCC

biological behavior of this tumor (1-14, 20, 21). Most studies available in the literature describe the use of cell culture techniques, flow cytometry, or transplantation assays in animal models to detect highly tumorigenic cells and thus assess the pathobiology of $\operatorname{HNSCC}(1,2,5,6,37)$. Our sample, in turn, was comprised of surgically removed human primary HNSCC specimens, and highly tumorigenic cells were identified in three different areas of the specimens using the immunostaining method. Sample characteristics, including mean age, gender, and exposure to risk factors (tobacco and alcohol use), were in line with the typical profile described for patients diagnosed with HNSCC (30, 38, 39).

Head and neck squamous cell carcinomas cells are heterogeneous within the same lesion, i.e., their cell hierarchy allows us to find subpopulations with exclusive biological behaviors, e.g., tumor growth and metastatic potential $(1,3,19,33)$. Our results showed positive CD44 and ALDH1 expression in both basal and suprabasal cells, which may indicate that the immunohistochemical technique here employed was not appropriate to identify cancer stem cells in HNSCCs based on these markers, as also reported by other authors $(31,34)$. Moreover, no specific markers have been established for the identification of cancer stem cell subpopulations in HNSCCs, as is the case with other tumors (37). Notwithstanding, immunohistochemistry did allow us to identify the location of positive cells in different tumoral areas (tumor center and invasive front), as well as in the different layers of adjacent nontumor epithelium. Also, our analysis revealed a positive correlation between the spatial localization of ALDH1positive cells and clinical outcomes, especially in the identification of tumors with a more aggressive behavior, despite the method's failure identifying cancer stem cells.

Immunostaining results obtained for the two tumor areas and non-tumor epithelium showed that tumors with ALDH1-positive cells also presented positive surrounding epithelial tissues. The concept of field cancerization, according to which carcinogen-induced changes would be present in HNSCC-related non-tumor tissues before morphological alterations can be found, was first proposed by Slaughter et al. (40) and later examined by Califano et al. (41). We believe that our finding of ALDH1-positive cells in adjacent non-tumor epithelium suggests that changes were already underway, as this enzyme tends to be present in cells with a high tumorigenic potential $(12,27,29)$.

Conversely, immunostaining results for CD44 in the two tumor areas and in adjacent non-tumor epithelium did not reveal any significant associations. No association was found between CD44 expression and clinical parameters. Notwithstanding, different results are reported in the literature with the use of other CD44-positive cell detection methods, e.g., flow cytometry $(2,37)$. The value of CD44 as a marker for highly tumorigenic cells has been questioned previously (26), and some studies have suggested that it may not be relevant in early diagnosis or as a prognostic marker in HNSCCs $(42,43)$.

Indeed, previous studies have shown conflicting results on the significance of CD44 expression in head and neck tumors $(9,24,44-48)$. Studies employing immunochemistry have shown that under-expression of CD44 standard form is 

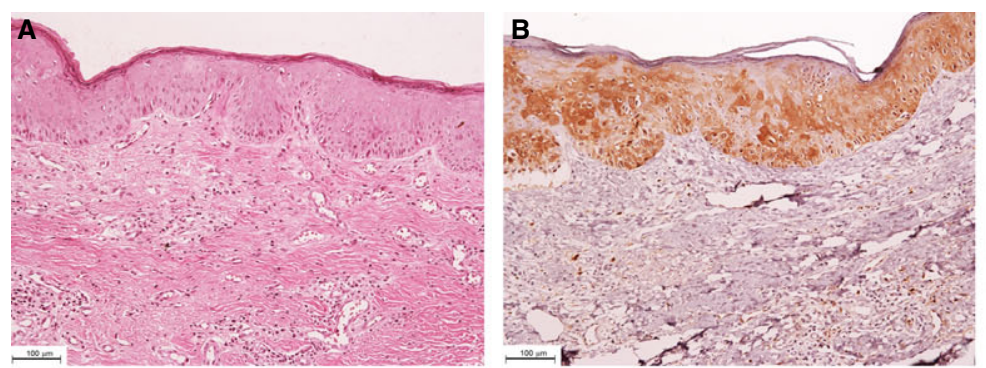

C
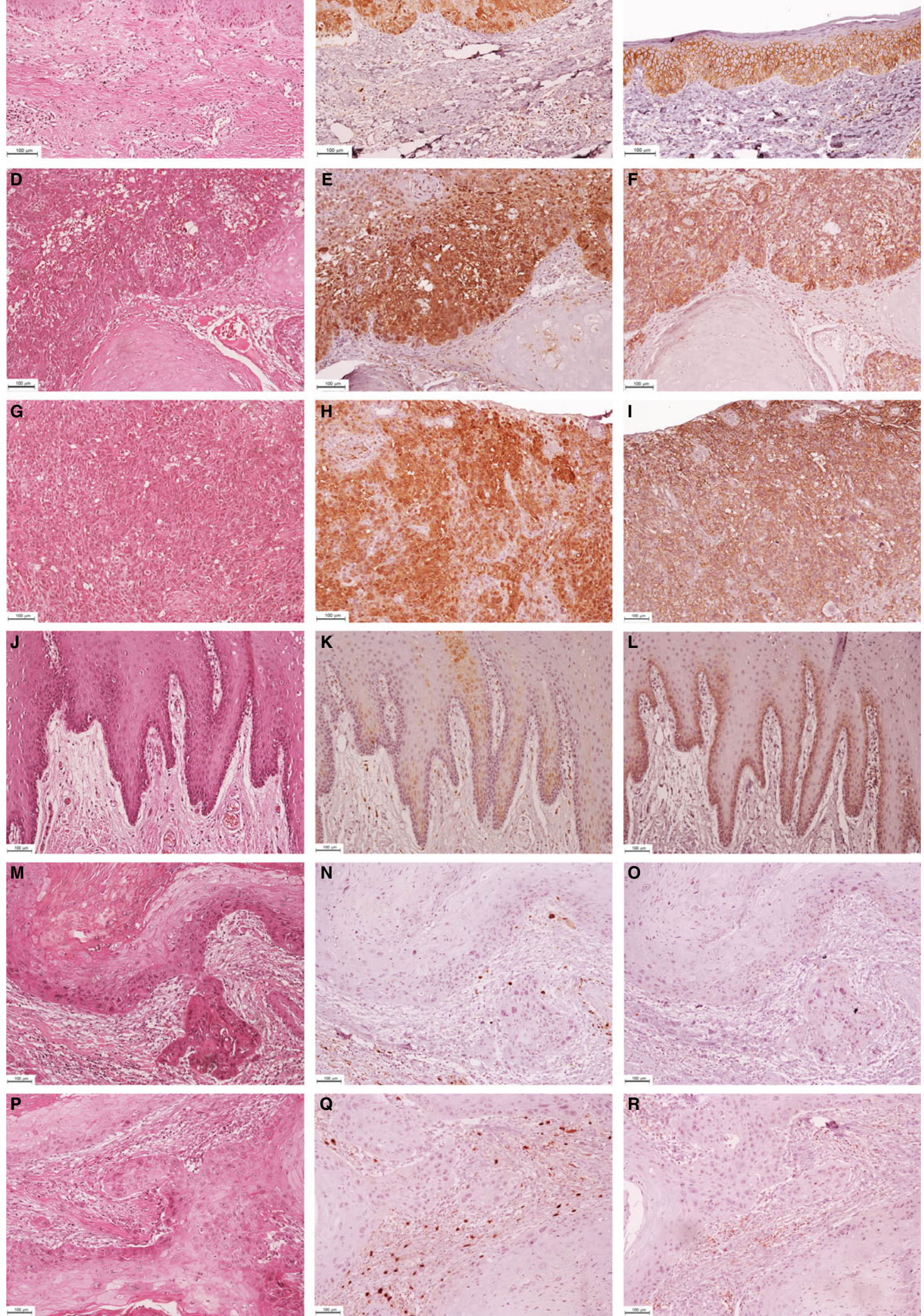

Figure 3 Positive immunostaining in non-tumor epithelium (a: HE; b: ALDH1; c: CD44), tumor invasive front (d: HE; e: ALDH1; f: CD44), and tumor center (g: HE; H: ALDH1; i: CD44). Negative immunostaining in non-tumor epithelium (j: HE; k: ALDH1; 1: CD44), tumor invasive front (m: HE; n: ALDH1; o: CD44), and tumor center (p: HE; q: ALDH1; r: CD44). 200× magnification. ALDH1 = aldehyde dehydrogenase 1; HE = hematoxylin and eosin. 
a predictor of reduced survival $(44,45,47)$. In contrast, others have shown CD44 to be highly expressed in normal, dysplastic, and tumoral head and neck epithelium $(11,24$,

Table 1 Patient characteristics and tumor features

\begin{tabular}{|c|c|c|}
\hline Clinical parameters & $\mathrm{n}$ & $\%$ \\
\hline \multicolumn{3}{|l|}{ Age } \\
\hline Mean & 58 & - \\
\hline Range & $37-78$ & - \\
\hline \multicolumn{3}{|l|}{ Gender } \\
\hline Male & 38 & 86.4 \\
\hline Female & 6 & 13.6 \\
\hline \multicolumn{3}{|l|}{ Tobacco } \\
\hline Current & 19 & 43.2 \\
\hline Former & 24 & 54.5 \\
\hline Never & 1 & 2.3 \\
\hline \multicolumn{3}{|l|}{ Alcohol } \\
\hline Current & 22 & 50 \\
\hline Former & 20 & 45.5 \\
\hline Never & 2 & 4.5 \\
\hline \multicolumn{3}{|l|}{ Follow-up (3-4 years) } \\
\hline Disease free & 30 & 68.2 \\
\hline $\begin{array}{l}\text { Metastasis/recurrence/ } \\
\text { death }\end{array}$ & 11 & 25 \\
\hline No data available & 3 & 6.8 \\
\hline \multicolumn{3}{|l|}{ Histopathological grading } \\
\hline Good & 22 & 50 \\
\hline Moderate & 17 & 38.6 \\
\hline Poor & 5 & 11.4 \\
\hline \multicolumn{3}{|l|}{ Size } \\
\hline $\mathrm{T} 1$ and $\mathrm{T} 2$ & 29 & 65.9 \\
\hline $\mathrm{T} 3$ and T4 & 15 & 34.1 \\
\hline \multicolumn{3}{|l|}{ Regional metastases } \\
\hline NO & 30 & 68.2 \\
\hline $\mathrm{N} 1, \mathrm{~N} 2$, and N3 & 14 & 31.8 \\
\hline \multicolumn{3}{|l|}{ Localization } \\
\hline Tongue & 9 & 20.5 \\
\hline Lower lip & 7 & 15.9 \\
\hline Floor of the mouth & 6 & 13.6 \\
\hline Palate & 4 & 9.1 \\
\hline Buccal mucosa & 3 & 6.8 \\
\hline Neck & 15 & 34.1 \\
\hline \multicolumn{3}{|l|}{ Non-tumor epithelium } \\
\hline $\begin{array}{l}\text { Normal oral } \\
\text { epithelium }\end{array}$ & 6 & 13.6 \\
\hline Epithelial hyperplasia & 14 & 31.8 \\
\hline Hyperkeratosis & 14 & 31.8 \\
\hline Acanthosis & 2 & 4.6 \\
\hline Epithelial dysplasia & 8 & 18.2 \\
\hline Total & 44 & 100 \\
\hline
\end{tabular}

26). The expression of specific CD44 variants may be reduced in tumors with a worse prognosis, but overall CD44 expression is not (46-48). Even though these varying results may be due to the use of different antibodies and assessment methods, CD44 immunostaining seems to be ineffective in detecting highly tumorigenic cells in HNSCCs.

CD44 appears to be present at different stages of carcinogenesis $(24,35)$. At first, CD44 binding to hyaluronic acid in the extracellular matrix stabilizes neoplastic cells in the invasive front, stimulating cell proliferation and consequently the growth of cancer cell islands $(24,25)$. Single-cell invasion shows a strongly positive expression of CD44 around the entire plasma membrane (35). Subsequently, the loss of CD44 expression suggests a second stage of tumor progression, in which cells lose their cell-cell adhesion, facilitating mobility and consequently the invasion and migration of neoplastic cells (22-25, 44).

Aldehyde dehydrogenase 1 staining in the tumor invasive front and non-tumor tissues showed positive associations with both clinical parameters (tumor size and presence of regional metastasis) and histopathological grading results. The lack of the same associations in the tumor center may be due the biological behavior of neoplastic cells in this region, i.e., less aggressive than cells of the invasive front (33). The association of ALDH1 staining with lymph node metastasis in HNSCC has been demonstrated previously (30). ALDH1-positive tumor cells have high tumor-initiating ability and also high invasion ability, properties that may be related to regional metastasis. In this sense, ALDH1 immunostaining may help identify tumor cells with an undifferentiated phenotype, suggestive of tumors with a stronger ability to invade surrounding tissues and develop metastases (13, 21, 27-30).

In our sample, ALDH1 immunostaining results were similar in tumor tissues and in non-tumor epithelium, suggesting that this marker could be used as an instrument to predict higher or lower risk of disease recurrence. Moreover, an association was observed between ALDH1 immunostaining in non-tumor epithelium and follow-up data: Of all adjacent epithelium specimens testing positive for ALDH1, 35.7\% showed metastases, local recurrence, or death within 3-4 years, whereas $93.8 \%$ of disease-free patients stained negative for ALDH1. This finding indicates the presence of cells with a highly tumorigenic potential even in cancer-free zones.

Table 2 Association between (aldehyde dehydrogenase 1) ALDH1 and CD44 expression in tumor center, invasive front, and non-tumor epithelium

\begin{tabular}{|c|c|c|c|c|c|c|c|c|c|c|c|}
\hline \multirow[b]{3}{*}{$A L D H 1$} & \multicolumn{5}{|c|}{ Non-tumor epithelium } & & \multicolumn{5}{|c|}{ Non-tumor epithelium } \\
\hline & \multicolumn{2}{|c|}{ Positive } & \multicolumn{2}{|c|}{ Negative } & \multirow[b]{2}{*}{$P$} & \multirow[b]{2}{*}{$C D 44$} & \multicolumn{2}{|c|}{ Positive } & \multicolumn{2}{|c|}{ Negative } & \multirow[b]{2}{*}{$\mathrm{P}$} \\
\hline & $\mathrm{n}$ & $\%$ & $\mathrm{n}$ & $\%$ & & & $\mathrm{n}$ & $\%$ & $\mathrm{n}$ & $\%$ & \\
\hline Tumor & & & & & & Tumor & & & & & \\
\hline Invasive front & & & & & & Invasive front & & & & & \\
\hline Positive & 19 & 67.9 & 3 & 18.8 & 0.005 & Positive & 19 & 54.3 & 4 & 44.4 & 0.716 \\
\hline Negative & 9 & 32.1 & 13 & 81.3 & & Negative & 16 & 45.7 & 5 & 55.6 & \\
\hline Tumor Center & & & & & & Tumor Center & & & & & \\
\hline Positive & 18 & 64.3 & 3 & 18.8 & 0.009 & Positive & 20 & 57.1 & 5 & 55.6 & 0.999 \\
\hline Negative & 10 & 35.7 & 13 & 81.3 & & Negative & 15 & 42.9 & 4 & 44.4 & \\
\hline Total & & & & & & $44 / 100 \%$ & & & & & \\
\hline
\end{tabular}

Pearson's chi-square test and Fisher's exact test, $P<0.05$.

Bold values are statistically significance of $P$ value. 
Table 3 Association between (aldehyde dehydrogenase 1) ALDH1 and CD44 expression in tumor center, invasive front, non-tumor epithelium, and clinical parameters

\begin{tabular}{|c|c|c|c|c|c|c|c|c|c|c|}
\hline & \multicolumn{5}{|c|}{$A L D H 1$} & \multicolumn{5}{|c|}{$C D 44$} \\
\hline & \multicolumn{2}{|c|}{ Positive } & \multicolumn{2}{|c|}{ Negative } & \multirow[b]{2}{*}{$\mathrm{P}$} & \multicolumn{2}{|c|}{ Positive } & \multicolumn{2}{|c|}{ Negative } & \multirow[b]{2}{*}{$\mathrm{P}$} \\
\hline & $\mathrm{n}$ & $\%$ & $\bar{n}$ & $\%$ & & $\mathrm{n}$ & $\%$ & $\bar{n}$ & $\%$ & \\
\hline \multicolumn{11}{|l|}{ Invasive front } \\
\hline \multicolumn{11}{|l|}{ Size } \\
\hline $\mathrm{T} 1$ and $\mathrm{T} 2$ & 10 & 45.5 & 19 & 86.4 & \multirow[t]{2}{*}{0.011} & 17 & 73.9 & 12 & 57.1 & \multirow[t]{2}{*}{0.393} \\
\hline $\mathrm{T} 3$ and $\mathrm{T} 4$ & 12 & 54.5 & 3 & 13.6 & & 6 & 26.1 & 9 & 42.9 & \\
\hline \multicolumn{11}{|l|}{ Regional metastases } \\
\hline No & 10 & 45.5 & 20 & 90.9 & \multirow[t]{2}{*}{0.004} & 17 & 73.9 & 13 & 61.9 & \multirow[t]{2}{*}{0.596} \\
\hline $\mathrm{N} 1, \mathrm{~N} 2$, and N3 & 12 & 54.5 & 2 & 9.1 & & 6 & 26.1 & 8 & 38.1 & \\
\hline \multicolumn{11}{|l|}{ Histopathological grading } \\
\hline Good & 6 & 27.3 & 16 & 72.7 & \multirow[t]{3}{*}{0.008} & 13 & 56.5 & 9 & 42.9 & \multirow[t]{3}{*}{0.630} \\
\hline Moderate & 12 & 54.5 & 5 & 22.7 & & 8 & 34.8 & 9 & 42.9 & \\
\hline Poor & 4 & 18.2 & 1 & 4.5 & & 2 & 8.7 & 3 & 14.3 & \\
\hline \multicolumn{11}{|l|}{ Tumor Center } \\
\hline \multicolumn{11}{|l|}{ Size } \\
\hline $\mathrm{T} 1$ and $\mathrm{T} 2$ & 11 & 52.4 & 18 & 78.3 & \multirow[t]{2}{*}{0.136} & 17 & 68 & 12 & 63.2 & \multirow[t]{2}{*}{0.988} \\
\hline $\mathrm{T} 3$ and $\mathrm{T} 4$ & 10 & 47.6 & 5 & 21.7 & & 8 & 32 & 7 & 36.8 & \\
\hline \multicolumn{11}{|l|}{ Regional metastases } \\
\hline N0 & 11 & 52.4 & 19 & 82.6 & 0.068 & 17 & 68 & 13 & 68.4 & 0.999 \\
\hline N1, N2, and N3 & 10 & 47.6 & 4 & 17.4 & & 8 & 32 & 6 & 31.6 & \\
\hline Histopathological grading & & & & & & & & & & \\
\hline Good & 7 & 33.3 & 15 & 65.2 & 0.129 & 12 & 48 & 10 & 52.6 & 0.693 \\
\hline Moderate & 11 & 52.4 & 6 & 26.1 & & 11 & 44 & 6 & 31.6 & \\
\hline Poor & 3 & 14.3 & 2 & 8.7 & & 2 & 8 & 3 & 15.8 & \\
\hline Non-tumor epithelium & & & & & & & & & & \\
\hline Size & & & & & & & & & & \\
\hline $\mathrm{T} 1$ and $\mathrm{T} 2$ & 15 & 53.6 & 14 & 87.5 & 0.051 & 25 & 71.4 & 4 & 44.4 & 0.235 \\
\hline $\mathrm{T} 3$ and $\mathrm{T} 4$ & 13 & 46.4 & 2 & 12.5 & & 10 & 28.6 & 5 & 55.6 & \\
\hline Regional metastases & & & & & & & & & & \\
\hline N0 & 17 & 60.7 & 13 & 81.3 & 0.284 & 26 & 74.3 & 4 & 44.4 & 0.117 \\
\hline $\mathrm{N} 1, \mathrm{~N} 2$, and N3 & 11 & 39.3 & 3 & 18.8 & & 9 & 25.7 & 5 & 55.6 & \\
\hline Histopathological grading & & & & & & & & & & \\
\hline Good & 10 & 35.7 & 12 & 75 & 0.026 & 18 & 51.4 & 4 & 44.4 & 0.382 \\
\hline Moderate & 13 & 46.4 & 4 & 25 & & 12 & 34.3 & 5 & 55.6 & \\
\hline Poor & 5 & 17.9 & 0 & 0 & & 5 & 14.3 & 0 & 0 & \\
\hline Follow-up & & & & & & & & & & \\
\hline Disease free & 15 & 53.6 & 15 & 93.8 & 0.019 & 25 & 71.4 & 5 & 55.6 & 0.281 \\
\hline Metastasis/recurrence/death & 10 & 35.7 & 1 & 6.3 & & 7 & 20 & 4 & 44.4 & \\
\hline No data available & 3 & 10.7 & 0 & 0 & & 3 & 8.6 & 0 & 0 & \\
\hline Total & & & $44 / 1$ & & & & & $44 / 1$ & & \\
\hline
\end{tabular}

Pearson's chi-square test and Fisher's exact test, $\mathrm{p}<0.05$.

Bold values are statistically significance of $P$ value.

In conclusion, CD44 and ALDH1 expression did not show a distinct spatial distribution pattern when invasive front and tumor center specimens were compared. Furthermore, while CD44 expression did not show a clear correlation with clinical outcomes, ALDH1 staining correlated well with tumor size, presence of regional metastasis, and histopathological grading. These results demonstrate that ALDH1 is predominantly found in more aggressive tumors, in both tumor areas and adjacent non-tumor epithelium, and may therefore be useful in improving treatment customization and the postoperative clinical management of patients with head and neck cancer.

\section{References}

1. Okamoto A, Chikamatsu K, Sakakura K, Hatsushika K, Takahashi G, Masuyama K. Expansion and characterization of cancer stem-like cells in carcinoma of the head and neck. Oral Oncol 2009; 45: 633-9.
2. Prince ME, Sivanandan R, Kaczorowski A, et al. Identification of a subpopulation of cells with cancer stem cell properties in head and neck squamous cell carcinoma. Proc Natl Acad Sci USA 2007; 104: 973-8.

3. Bhaijee F, Pepper DJ, Pitman KT, Bell D. Cancer stem cells in head and neck squamous cell carcinoma: a review of current knowledge and future applications. Head Neck 2012; 34: 894-9.

4. Sayed SI, Dwivedi RC, Katna R, Garg A, Pathak KA, Nutting $\mathrm{CM}$. Implications of understanding cancer stem cell (CSC) biology in head and neck squamous cell cancer. Oral Oncol 2011; 47: 237-43.

5. Harper LJ, Piper K, Common J, Fortune F, Mackenzie IC. Stem cell patterns in cell lines derived from head and neck squamous cell carcinoma. J Oral Pathol Med 2007; 36: 594-603.

6. Chen C, Wei Y, Hummel M, et al. Evidence for epithelialmesenchymal transition in cancer stem cells of head and neck squamous cell carcinoma. PLOS ONE 2011; 6: e16466.

7. Oliveira LR, Oliveira-Costa JP, Araujo IM, Soave DF, Zanetti JS, Soares FA. Cancer stem cell immunophenotypes in oral squamous cell carcinoma. J Oral Pathol Med 2011; 40: 135-42. 
8. Krishnamurthy S, Dong Z, Vodopyanov D, et al. Endothelial cell-initiated signaling promotes the survival and self-renewal of cancer stem cells. Cancer Res 2010; 70: 9969-78.

9. Kosunen A, Pirinen R, Ropponen K, et al. CD44 expression and its relationship with MMP-9, clinicopathological factors and survival in oral squamous cell carcinoma. Oral Oncol 2007; 43: 51-9.

10. Wang SJ, Bourguignon LYW. Role of hyaluronan-mediated CD44 signaling in head and neck squamous cell carcinoma progression and chemoresistance. Am J Pathol 2011; 178: 956-63.

11. Kokko LL, Hurme S, Maula SM, et al. Significance of sitespecific prognosis of cancer stem cell marker CD44 in head and neck squamous cell carcinoma. Oral Oncol 2011; 47: 510-6.

12. Chen YC, Chen YW, Hsu HS, et al. Aldehyde dehydrogenase 1 is a putative marker for cancer stem cells in head and neck squamous cancer. Biochem Biophys Res Commun 2009; 385: 307-13.

13. Clay MR, Tabor M, Owen JR, et al. Single-marker identification of head and neck squamous cell carcinoma cancer stem cells with aldehyde dehydrogenase. Head Neck 2010; 32: 1195-201.

14. Krishnamurthy S, Nör JE. Head and neck cancer stem cells. $J$ Dent Res 2012; 91: 334-40.

15. Avoranta ST, Korkeila EA, Ristamäki RH, et al. ALDH1 expression indicates chemotherapy resistance and poor outcome in node-negative rectal cancer. Hum Pathol 2013; 44: 966-74.

16. Reya T, Morrison SJ, Clarke MF, Weissman IL. Stem cells, cancer, and cancer stem cells. Nature 2001; 414: 105-11.

17. Douville J, Beaulieu R, Balicki D. ALDH1 as a functional marker of cancer stem and progenitor cells. Stem Cells Dev 2009; 18: 17-25.

18. Wicha MS, Liu S, Dontu G. Cancer stem cells: an old idea-a paradigm shift. Cancer Res 2006; 66: 1883-90.

19. Driessens G, Beck B, Caauwe A, Simons BD, Blanpain C. Defining the mode of tumour growth by clonal analysis. Nature 2012; 488: 527-30.

20. Zhang Z, Sant'Ana Filho M, Nör JE. The biology of head and neck cancer stem cells. Oral Oncol 2012; 48: 1-9.

21. Minato T, Yamamoto Y, Seike J, et al. Aldehyde dehydrogenase 1 expression is associated with poor prognosis in patients with esophageal squamous cell carcinoma. Ann Surg Oncol 2013; 20: 209-17.

22. Naor D, Wallach-Dayan SB, Zahalka MA, Sionov RV. Involvement of CD44, a molecule with a thousand faces, in a cancer dissemination. Semin Cancer Biol 2008; 18: 260-7.

23. Aruffo A, Stamenkovic I, Melnick M, Underhill CB, Seed B. CD44 is the principal cell surface receptor for hyaluronate. Cell 1990; 61: 1301-13.

24. Bánkfalvi A, Krabort M, Buchwalow IB, Végh A, Felszeghy E, Piffkó J. Gains and losses of adhesion molecules (CD44, Ecadherin and $\beta$-catenin) during oral carcinogenesis and tumor progression. J Pathol 2002; 198: 343-51.

25. Gergolios A, Batistatou A, Charalabopoulos A, Manolopoulos $\mathrm{L}$, Charalabopoulos K. The role of CD44 adhesion molecule in oral cavity cancer. Exp Oncol 2006; 28: 94-8.

26. Mack B, Gires O. CD44s and CD44v6 expression in head and neck epithelia. PLOS ONE 2008; 3: e3360.

27. Duester G. Retinoic acid synthesis and signaling during early organogenesis. Cell 2008; 134: 921-31.

28. Duong V, Rochette-Egly C. The molecular physiology of nuclear retinoic acid receptors. From health to disease. Biochim Biophys Acta 2011; 1812: 1023-31.

29. Ginestier C, Hur MH, Charafe-Jauffret E, et al. ALDH1 is a marker of normal and malignant human mammary stem cells and a predictor of poor clinical outcome. Cell Stem Cell 2007; 1: $555-67$.

30. Michifuri Y, Hirohashi Y, Torigoe T, et al. High expression of ALDH1 and SOX2 diffuse staining pattern of oral squamous cell carcinomas correlates to lymph node metastasis. Pathol Int 2012; 62: 684-9.

31. Deng S, Yang X, Lassus H, et al. Distinct expression levels and patterns of stem cell marker, aldehyde dehydrogenase isoform 1 (ALDH1), in human epithelial cancers. PLOS ONE 2010; 5: e10277.

32. Takes RP, Rinaldo A, Silver CE, et al. Future of the TNM classification and staging system in head and neck cancer. Head Neck 2010; 32: 1693-711.

33. Bryne M, Koppang H, Lilleng R, Kjaerheim A. Malignancy grading of the deep invasive margins of oral squamous cell carcinomas has high prognostic value. J Pathol 1992; 166: 375-81.

34. Oliveira DT, Odell EW. Expression of CD44 variant exons by normal oral epithelia. Oral Oncol 1997; 33: 260-2.

35. Oliveira DT, Sherriff M, Odell EW. Expression of CD44 variant exons by primary and metastatic oral squamous cell carcinomas. J Oral Pathol Med 1998; 27: 303-7.

36. Visus C, Ito D, Amoscato A, Maciejewska-Franczak M, Abdelsalem A, Dhir R. Identification of human aldehyde dehydrogenase 1 family member A1 as a novel CD8 + T-celldefined tumor antigen in squamous cell carcinoma of the head and neck. Cancer Res 2007; 67: 10538-45.

37. Joshua B, Kaplan MJ, Doweck I, et al. Frequency of cells expressing CD44, a head and neck cancer stem cell marker: correlation with tumor aggressiveness. Head Neck 2012; 34: 42-9.

38. Warnakulasuriya S. Global epidemiology of oral and oropharyngeal cancer. Oral Oncol 2009; 45: 309-16.

39. Jemal A, Bray F, Center MM, Ferlay J, Ward E, Forman D. Global cancer statistics. CA Cancer J Clin 2011; 61: 69-90.

40. Slaughter DP, Southwick HW, Smejkal W. "Field cancerization" in oral stratified squamous epithelium: clinical implications of multicentric origin. Cancer 1953; 6: 963-8.

41. Califano J, Van der Riet P, Westra W, et al. Genetic progression model for head and neck cancer: implications for field cancerization. Cancer Res 1996; 56: 2488-92.

42. Bloor BK, Rajarajan A, Jaafary-Haghighat K, Odell EW. Transcription and expression of CD44 variant exons by oropharyngeal squamous cell carcinomas. Int J Oncol 2002; 21: 907-13.

43. Bloor BK, Jelvagharan M, White KN, Odell EW. Characterization of CD44 splicing patterns in normal keratinocytes, dysplastic and squamous carcinoma cell lines. Int J Oncol 2001; 18: 1053-9.

44. Carinci F, Stabellini G, Calvitti M, et al. CD44 as prognostic factor in oral and ororpharyngeal squamous cell carcinoma. $J$ Craniofac Surg 2002; 13: 85-9.

45. Gonzalez-Moles MA, Bravo M, Ruiz-Avila I, et al. Adhesion molecule CD44 as a prognostic factor in tongue cancer. Anticancer Res 2003; 23: 5197-202.

46. Sato S, Miyauchi M, Takekoshi T, et al. Reduced expression of CD44 variant 9 is related to lymph node metastasis and poor survival in squamous cell carcinoma of tongue. Oral Oncol 2000; 36: 545-9.

47. Stoll C, Baretton G, Soost F, Terpe HJ, Domide P, Löhrs U. Prognostic importance of the expression of CD44 splice variants in oral squamous cell carcinomas. Oral Oncol 1999; 35: 484-9.

48. Wang SJ, Wong G, de Heer AM, Xia W, Bourguignon LY. CD44 variant isoforms in head and neck squamous cell carcinoma progression. Laryngoscope 2009; 119: 1518-30. 
506

\section{Acknowledgements}

The authors are grateful to the Department of Otolaryngology, Division of Head and Neck Surgery, and Department of Pathology of Hospital de Clínicas de Porto Alegre, Brazil; to the staff of the Prof. Dr. J.J. Barbachan Histopathology Laboratory, School of Dentistry, Universidade Federal do Rio Grande do Sul, Brazil; and to the Angiogenesis Research Laboratory, School of Dentistry University of Michigan, USA. This study was supported by grants received from Fundação de Amparo à Pesquisa do Estado do Rio Grande do Sul (FAPERGS;
Edital Proap no. 04/2004, protocol no. 0410882), Coordenação de Aperfeiçoamento de Pessoal de Nível Superior (CAPES; PhD scholarship), and Conselho Nacional de Desenvolvimento Científico e Tecnológico (CNPq; protocol no. 472969/2009-9).

\section{Conflict of interest}

The authors have no conflicts of interest to disclose. 